\title{
Article \\ Adolescents in the Time of COVID: Findings from India and Nepal
}

\author{
Nitasha Nagaraj ${ }^{1, * \mathbb{C}}$, Megan Landry ${ }^{1}$, Richa Hingorani ${ }^{2}$, Jaya Luintel ${ }^{3}$ and Amita Vyas ${ }^{1}$ \\ 1 Department of Prevention and Community Health, Milken Institute School of Public Health, The George \\ Washington University, Washington, DC 20037, USA; mmlandry@gwu.edu (M.L.); avyas@gwu.edu (A.V.) \\ 2 India Program Lead, Girl Rising, New Delhi 110067, India; richa@girlrising.org \\ 3 The StoryKitchen, Patan 44700, Nepal; luinteljaya@gmail.com \\ * Correspondence: nitasha@gwu.edu
}

check for updates

Citation: Nagaraj, N.; Landry, M.; Hingorani, R.; Luintel, J.; Vyas, A. Adolescents in the Time of COVID: Findings from India and Nepal. Adolescents 2022, 2, 1-10. https:/ / doi.org/10.3390/adolescents2010001 Academic Editors: Margarita Azmitia and Laura L. Hayman

Received: 2 December 2021

Accepted: 5 January 2022

Published: 18 January 2022

Publisher's Note: MDPI stays neutral with regard to jurisdictional claims in published maps and institutional affiliations.

Copyright: (C) 2022 by the authors. Licensee MDPI, Basel, Switzerland. This article is an open access article distributed under the terms and conditions of the Creative Commons Attribution (CC BY) license (https:// creativecommons.org/licenses/by/ $4.0 /)$.

\begin{abstract}
Historically, epidemics and humanitarian crises have disproportionately impacted the most vulnerable, impacting mostly girls and women living in low-to-middle income countries. Entrenched inequalities in gender norms and access to education often leave young girls inadequately equipped to effectively protect themselves and their families during an outbreak. There is no exception now as the COVID-19 pandemic has yielded unintended consequences for both adolescent boys and girls. This quantitative research study explores adolescent boys' and girls' COVID-19 related perceptions of risk and related behaviors and challenges related to school closures almost one year after the start of the pandemic in India and Nepal. Males were more likely to report completing online/mobile learning and assignments provided by school, whereas females reported a higher percentage of studying with their own books, using other learning resources, or doing nothing while schools have been shut down. Girls were more likely to report wanting to return to school after the pandemic was over. Compared to girls, boys were more likely to report spending more time on household chores than they did before the pandemic. COVID-19 recovery efforts are imperative in alleviating the pandemic's adverse consequences for adolescents' education, health well-being, and gender inequities.
\end{abstract}

Keywords: adolescents; gender; education; COVID-19 pandemic

\section{Introduction}

The novel coronavirus (COVID-19) pandemic disrupted the lives of everyone in communities around the world. Owing to the virus' rate of transmission and infectivity, countries worldwide implemented curfews, national lockdowns, and restrictions to all facets of life in the hopes of flattening the pandemic curve and mitigate the spread of the virus. These mitigation strategies were especially difficult for children and adolescents and sparked not only a health crisis but an educational crisis as well. At the peak of school closures in April 2020, 94\% of students or 1.6 billion children were out of school worldwide, and still, around 700 million students today are studying from home [1]. Early evidence from several high-income countries has already revealed increases in inequality. Data from UNICEF's Multiple Indicator Cluster Surveys (MICS) in low- and middle-income countries found that missing school reduced basic literacy and numeracy skills among children ages 9-14 [2]. Further, evidence from previous pandemics has found that school closures not only have long-term negative consequences for adolescents' educational outcomes, but also reinforces existing gender and health inequalities [3].

Schools not only provide an academic education, but they provide students with nutritious meals, facilitate relationships with peers, teachers, and role models, and create safe spaces for students to share fears and dangers [4]. COVID-19 poses an even higher risk to girls' education and well-being, as they are now even more vulnerable to facing inequities young girls face, often forcing them into child marriage, early motherhood, increased household work, and gender-based violence [5,6]. Furthermore, the past year has 
proven to be even harder on adolescents as more of their time has been spent on increased responsibility for caregiving and domestic chores and much less focused on education [7]. With 1.2 billion adolescents (aged 10-19 years of age) in the world, adolescents make up $16 \%$ of the world population [8] and $90 \%$ of these adolescents live in low- to middleincome countries [9]. It is imperative that COVID-19 recovery efforts focus on alleviating the pandemic's adverse consequences for adolescents' education, health well-being, and gender inequities.

South Asia

Adolescents account for one-fifth (or 20\%) of India's population, home to the largest population of adolescents and young adults in any country worldwide. With such a large population of adolescents in India, understanding the impact of the pandemic is even more critical. As seen in previous cases of humanitarian crises and/or other public health emergencies, access to education is limited, more so for girls as factors, such as accessibility of schools, household work, sibling care, early marriage, and motherhood, become a priority [10]. For boys, this often led to feelings of insecurity and uncertainty, frustration, and a sense of futility fueling more risk-taking behaviors, such as early sexual activity and aggression and violence toward others [10,11].

While much work in the past few decades has been performed to promote girls' education in India, with the current COVID-19 pandemic, much of this will likely change. In 2001 the girls' literacy rate was 53.7\% and in 2011, the rate improved even more to $65 \%$ [12]. Along with these improvements in literacy, India has witnessed a significant increase in enrollment, particularly among girls, in primary and secondary schools during this time [12]. However, on 24 March 2020, the Indian government instituted a nationwide lockdown to mitigate the spread of the virus. The lockdown was lifted on 8 June 2020 to begin a phased re-opening; however [13], most educational institutions continued to be closed without a clear view regarding when there would be a re-opening [14].

Similarly, in Nepal, adolescents account for $22 \%$ of the population. A country that is characterized by persistent poverty and slow economic growth [15], education is often overlooked. The barriers to women participating in education are due to deeply rooted socio-cultural realities [16], particularly in rural areas [15]. In a 2015 study conducted by Panthe and McCutcheon, boys were found to have at least two or more years of schooling than their female counterparts, and this gap was further widened in rural areas, with boys having three or more years of schooling than girls [17]. For many young girls in Nepal, oftentimes they were taken out of school to get married or help with housework [18] Further, for many families educating a girl is not perceived as worthy or valuable compared to investing in boys [18]. Finally, gender has been shown to be the single strongest determinant of school participation among rural youth in Nepal by a national study (World Bank, 2020). Similar to India, there is reason to warrant that school closures in Nepal will only exacerbate the gender gaps in education and girls' empowerment. In response to the COVID-19 pandemic, Nepal closed all schools on 19 March 2020, which led to a national lockdown later in the month of March until July 2020 [18]. The Government of Nepal's Ministry of Education did not release guidelines on re-opening schools until November 2020 [17].

In the age-and gender-stratified settings of India and Nepal, little is known regarding the experiences of adolescents during the time of COVID-19, particularly as self-reported by adolescents themselves. The present study explores adolescent boys' and girls' COVID19 related perceptions or risk, COVID-19 related behaviors, and challenges related to school closures and learning almost one year after the start of the pandemic in South Asia.

\section{Materials and Methods}

\subsection{Study Sample}

The data for this study were derived from a larger study via a self-reported survey of 481 adolescents ages 10-15 years old in public schools located in Delhi, India (urban), Uttar 
Pradesh, India (rural), and Gandaki Province Nepal (semi-urban). The adolescent participants were part of local existing after-school programs and interventions implemented by non-profit community organizations, and a convenience sample was recruited. The sample size was based on a covariance analysis by gender and location, and the expected prevalence of COVID-related variables. Data for the current study were collected in February 2021 and included $57 \%$ female adolescents and $43 \%$ male adolescents (Table 1). The average age of survey respondents was 12.42 years, with just under half of respondents residing in Delhi, India and approximately $29 \%$ in both Uttar Pradesh, India and Gandaki Province, Nepal.

Table 1. Sample Characteristics.

\begin{tabular}{cccc}
\hline Variables & Total & Female $(\boldsymbol{n}=\mathbf{2 7 4 )}$ & Male $(\boldsymbol{n}=\mathbf{2 0 7})$ \\
\hline Mean Age (SE) & $12.42(0.041)$ & $12.42(1.33)$ & $12.43(1.19)$ \\
\hline Region & & & \\
\hline Uttar Pradesh, India & $28.96(138)$ & $78.99(109)$ & $51.01(29)$ \\
\hline Delhi, India & $42.20(203)$ & $47.86(67)$ & $52.14(73)$ \\
\hline Gandaki Province, Nepal & $29.11(140)$ & $48.28(98)$ &
\end{tabular}

\subsection{Data Collection}

The in-country research teams completed virtual data collection training provided by the USA research team and followed a standardized protocol in delivering the survey to participants, which was completed via paper and pencil in an afterschool setting with no teachers or school authority figures present. The survey was created in English then translated into Hindi/Nepali by two native Hindi and Nepali speakers, and translated back to English to ensure that proper dialect and language nuances were captured. Prior to the start of data collection, the in-country community partners contacted parents of the participants to provide an overview of the project, to review and provide a copy of the consent form. Verbal parental consent was obtained for their adolescent to participate in the survey.

Upon survey completion, the in-country research team entered the completed surveys into a pre-populated survey database in Microsoft Excel. Ten percent of the paper surveys were re-entered for data quality assurance. The final dataset was further checked by the in-country research team and the USA research team to verify missing, duplicate, or incomplete data. The final dataset was securely transferred to the USA research team to further clean and analyze the sample.

\subsection{Measures}

The survey instrument included a total of 68 items collecting data on participants sociodemographic characteristics, school and household environment, relationships with friends and family, gendered experiences, and perceptions of those experiences, in addition to 10 questions related to the current COVID-19 pandemic. The present study focuses on the COVID-19 specific survey questions that were adapted from the GAGE COVID-19 phone survey and modified by our community partners for literacy and understanding within a South Asian adolescent context [19]. Table 2 presents the COVID-19 questions presented in the current study. 
Table 2. COVID Survey Questions.

\begin{tabular}{|c|c|}
\hline Measure & Scale \\
\hline $\begin{array}{l}\text { In your community, how many households do } \\
\text { you think have been affected by infection from } \\
\text { the Coronavirus (the virus causing COVID-19), } \\
\text { with someone in the household becoming sick? }\end{array}$ & $\begin{array}{l}0=\text { None } \\
1=\text { Many }, \text { including my own household } \\
2=\text { Many }, \text { but not my own household } / \text { family } \\
3=\text { Some } / \text { Few }\end{array}$ \\
\hline $\begin{array}{l}\text { Do you have a mask (even a homemade one or } \\
\text { a face covering) to cover your mouth and nose } \\
\text { when you leave your house? }\end{array}$ & $\begin{array}{l}0=\text { no } \\
1=\text { yes }\end{array}$ \\
\hline $\begin{array}{c}\text { Do you wear your mask every time you leave } \\
\text { your house? }\end{array}$ & $\begin{array}{l}0=\text { no } \\
1=\text { yes }\end{array}$ \\
\hline $\begin{array}{l}\text { What is the MAIN thing you are doing to } \\
\text { continue learning while schools are closed? }\end{array}$ & $\begin{array}{l}0=\text { Nothing } \\
1=\text { Working on assignments provided by } \\
\text { school } \\
2=\text { Spending time studying with own books } \\
3=\text { Online/Mobile learning } \\
4=\text { Other learning resources }\end{array}$ \\
\hline $\begin{array}{l}\text { Is your school providing any support for } \\
\text { learning while schools are closed? }\end{array}$ & $\begin{array}{l}0=\text { no } \\
1=\text { yes }\end{array}$ \\
\hline $\begin{array}{l}\text { I want to return to school when } \\
\text { COVID-19 restrictions are over and } \\
\text { schools open }\end{array}$ & $\begin{array}{l}0=\text { no } \\
1=\text { yes }\end{array}$ \\
\hline $\begin{array}{l}\text { I will not be able to return to school when } \\
\text { COVID-19 restrictions are over, even if I } \\
\text { wanted to }\end{array}$ & $\begin{array}{l}0=\text { no } \\
1=\text { yes }\end{array}$ \\
\hline $\begin{array}{l}\text { I spend more time on household chores now } \\
\text { than before the COVID-19 situation }\end{array}$ & $\begin{array}{l}0=\text { no } \\
1=\text { yes }\end{array}$ \\
\hline $\begin{array}{l}\text { I spend more time taking care of children and } \\
\text { the elderly now than before COVID-19. }\end{array}$ & $\begin{array}{l}0=\text { no } \\
1=\text { yes }\end{array}$ \\
\hline $\begin{array}{l}\text { What is the MAIN challenge you are facing to } \\
\text { continue learning while schools are closed? }\end{array}$ & $\begin{array}{l}1=\text { I don't know what to do } \\
2=\text { I don't have a reliable internet connection } \\
3=\text { I don't have reliable electricity } \\
4=\text { I do not understand homework or } \\
\text { assignments provided } \\
5=\text { Limited adult support from family } \\
6=\text { Limited adult support for teachers } \\
7=\text { No time to study because of } \\
\text { chores/household responsibilities } \\
8=\text { Too much stress to focus on learning } \\
9=\text { I am not allowed to study at home } \\
10=\text { I am not interested in studying at home } \\
11=\text { Other }\end{array}$ \\
\hline
\end{tabular}

\subsection{Analysis}

Univariate analyses were conducted to examine frequencies and distributions of the study variables of interest. Chi-square tests were conducted to examine bivariate relationships between the COVID-19 survey questions and gender as well as geographic location. This study was reviewed and approved by The George Washington University Internal Review Board (IRB \#191568).

\section{Results}

Overall, nearly $50 \%$ of survey respondents did not think any households had been affected by COVID-19 at the time of the survey. When examining bivariate relationships, slightly more females (53\%) than males $(44 \%)$ did not think any households had been affected by COVID-19 $(p<0.01)$, whereas $70 \%$ of respondents in Delhi did not think any 
households had been affected by COVID-19, followed by 52\% in Uttar Pradesh and 33\% in Nepal ( $p<0.001$ ) (see Table 3). Only 5.6\% of respondents reported that many, including their own households, were affected by COVID-19.

Table 3. Household perceptions and risk reduction behavior.

\begin{tabular}{|c|c|c|c|c|c|c|c|c|}
\hline Variables. & $\begin{array}{l}\text { Total } \\
\%(n)\end{array}$ & $\begin{array}{l}\text { Female } \\
(n=274)\end{array}$ & $\begin{array}{c}\text { Male } \\
(n=207)\end{array}$ & $p$-Value & $\begin{array}{c}\mathrm{UP} \\
(n=138)\end{array}$ & $\begin{array}{c}\text { Delhi } \\
(n=139)\end{array}$ & $\begin{array}{c}\text { Nepal } \\
(n=204)\end{array}$ & $p$-Value \\
\hline \multicolumn{9}{|c|}{ How many households do you think have been affected by COVID } \\
\hline None & $49.17(236)$ & $52.92(145)$ & $44.17(91)$ & \multirow{4}{*}{$<0.01$} & $52.17(72)$ & $69.78(97)$ & $33.00(67)$ & \multirow{4}{*}{$<0.001$} \\
\hline $\begin{array}{l}\text { Many, including } \\
\text { my household }\end{array}$ & $5.62(27)$ & $2.55(7)$ & $9.71(20)$ & & $0.72(1)$ & $3.60(5)$ & $10.34(21)$ & \\
\hline $\begin{array}{l}\text { Many, but not my } \\
\text { household }\end{array}$ & $13.12(63)$ & $11.68(32)$ & $15.05(31)$ & & $13.77(19)$ & $7.91(11)$ & $16.26(33)$ & \\
\hline Some/Few & $32.08(154)$ & $32.85(90)$ & $31.07(64)$ & & $33.33(46)$ & $18.71(26)$ & $40.39(82)$ & \\
\hline \multicolumn{9}{|c|}{ Do you have a mask (even a homemade one or a face covering) to cover your mouth and nose when you leave your house? } \\
\hline Yes & $85.65(412)$ & $86.50(237)$ & $84.54(175)$ & \multirow{2}{*}{0.545} & $83.33(115)$ & $90.00(126)$ & $84.24(171)$ & \multirow{2}{*}{0.213} \\
\hline No & $14.35(69)$ & $13.50(37)$ & $15.46(32)$ & & $16.67(23)$ & $10.00(14)$ & $15.76(32)$ & \\
\hline \multicolumn{9}{|c|}{ Do you wear your mask every time you leave your house? } \\
\hline Yes & $81.29(391)$ & $79.20(217)$ & $84.06(174)$ & \multirow{2}{*}{0.176} & $63.04(87)$ & $92.14(129)$ & $86.21(175)$ & \multirow{2}{*}{$<0.001$} \\
\hline No & $18.71(90)$ & $20.80(57)$ & $15.94(33)$ & & $36.96(51)$ & $7.86(11)$ & $13.79(28)$ & \\
\hline
\end{tabular}

The vast majority of respondents reported having a mask to cover their face and nose when they left their house (86\%) and 81\% reported wearing their mask every time they left their home. There were no differences by gender in having or wearing a mask when leaving one's home, but respondents in Delhi (92\%) reported a higher percentage of wearing their mask when leaving their home, compared to Nepal (86\%) and Uttar Pradesh $(63 \%)(p<0.001)$.

When asked about school or learning activities during COVID-19 and perceptions of the pandemic's impact on future schooling, nearly $40 \%$ of survey respondents reported that their main mode of learning during school closures is online or mobile learning, followed by $29 \%$ completing assignments provided by the school (Table 4 ). Males were more likely to report completing online/mobile learning (45\%) and assignments provided by school $(31 \%)$, whereas females reported a higher percentage of studying with their own books $(23 \%)$, using other learning resources $(8 \%)$, or doing nothing while schools have been shut down $(5 \%)(p<0.01)$. There were also significant differences by geographic location. Respondents in Uttar Pradesh reported a higher percentage of doing nothing while schools have been shut down (12\%) compared to Delhi and Nepal (1.43\% and $0.49 \%$, respectively, $p<0.001)$. Uttar Pradesh respondents also reported a higher percentage of studying with their own books (35\%) and a lower percentage of online/mobile learning (17\%), compared to Delhi and Nepal $(p<0.001)$.

The majority of respondents reported that their schools were providing support during the shutdown with no differences by gender, but Uttar Pradesh reported a significantly lower percentage of school support during the shutdown $(62 \%, p<0.001)$. Girls were more likely to report wanting to return to school after the pandemic was over (75\% vs. 59\%, $p<0.001)$. Compared to Uttar Pradesh (71\%) and Nepal $(74 \%)$, individuals in Delhi reported a lower percentage of wanting to return to school after the pandemic $(59 \%, p<0.01)$. 
Table 4. Experiences with School Closures During COVID-19.

\begin{tabular}{|c|c|c|c|c|c|c|c|c|}
\hline Variables & $\begin{array}{l}\text { Total } \\
\%(n)\end{array}$ & $\begin{array}{c}\text { Female } \\
(n=274)\end{array}$ & $\begin{array}{c}\text { Male } \\
(n=207)\end{array}$ & $p$-Value & UP & Delhi & Nepal & $p$-Value \\
\hline \multicolumn{9}{|c|}{ What is the MAIN thing you are doing to continue learning while schools are closed? } \\
\hline Nothing & $3.95(19)$ & $5.47(15)$ & $1.93(4)$ & \multirow{5}{*}{$<0.01$} & $11.59(16)$ & $1.43(2)$ & $0.49(1)$ & \multirow{5}{*}{$<0.001$} \\
\hline $\begin{array}{c}\text { Assignments } \\
\text { provided by school }\end{array}$ & $29.31(141)$ & $27.74(76)$ & $31.40(65)$ & & $27.54(38)$ & $16.43(23)$ & $39.41(80)$ & \\
\hline $\begin{array}{l}\text { Studying with } \\
\text { own books }\end{array}$ & $19.96(96)$ & 22.99 (63) & $15.94(33)$ & & $34.78(48)$ & $17.86(25)$ & $11.33(23)$ & \\
\hline $\begin{array}{l}\text { Online/Mobile } \\
\text { learning }\end{array}$ & 39.92 (192) & 35.77 (98) & $45.41(94)$ & & $17.39(24)$ & 59.29 (83) & $41.87(85)$ & \\
\hline $\begin{array}{c}\text { Other learning } \\
\text { resources }\end{array}$ & $6.86(33)$ & $8.03(22)$ & $5.31(11)$ & & $8.70(12)$ & $5.00(7)$ & $6.90(14)$ & \\
\hline \multicolumn{9}{|c|}{ Is your school providing any support for learning while schools are closed? } \\
\hline Yes & $79.83(384)$ & $78.83(216)$ & $81.16(168)$ & \multirow{2}{*}{0.529} & $62.32(86)$ & $89.29(125)$ & $85.22(173)$ & \multirow{2}{*}{$<0.001$} \\
\hline No & $20.17(97)$ & $21.17(58)$ & $18.84(39)$ & & $37.68(52)$ & $10.71(15)$ & $14.78(30)$ & \\
\hline \multicolumn{9}{|c|}{ I want to return to school when COVID-19 restrictions are over and schools open. } \\
\hline Yes & $67.98(327)$ & $74.82(205)$ & $58.94(122)$ & \multirow{2}{*}{$<0.001$} & $71.01(98)$ & $58.57(82)$ & $72.41(147)$ & \multirow{2}{*}{$<0.01$} \\
\hline No & $32.02(154)$ & $25.18(69)$ & $41.06(85)$ & & $28.99(40$ & $41.43(58)$ & $27.59(56)$ & \\
\hline \multicolumn{9}{|c|}{ I will not be able to return to school when COVID-19 restrictions are over, even if I wanted to. } \\
\hline Yes & $22.25(107)$ & $21.53(59)$ & $23.19(48)$ & \multirow{2}{*}{0.666} & $24.64(34)$ & $8.57(12)$ & $30.05(61)$ & \multirow{2}{*}{$<0.001$} \\
\hline No & $77.75(374)$ & $78.47(215)$ & $76.81(159)$ & & $75.36(104)$ & $91.43(128)$ & $69.95(142)$ & \\
\hline \multicolumn{9}{|c|}{ I spend more time on household chores now than before the COVID-19 situation. } \\
\hline Yes & $33.68(162)$ & $28.10(77)$ & $41.06(85)$ & $<0.01$ & $28.26(39)$ & $11.43(16)$ & $52.71(107)$ & $<0.001$ \\
\hline No & $66.32(319)$ & $71.90(197)$ & $58.94(122)$ & & $71.74(99)$ & $88.57(124)$ & $47.29(96)$ & \\
\hline \multicolumn{9}{|c|}{ I spend more time taking care of children and the elderly now than before COVID-19. } \\
\hline Yes & 31.67 (152) & $26.37(72)$ & $38.65(80)$ & \multirow{2}{*}{$<0.01$} & $21.17(29)$ & $17.86(25)$ & $48.28(98)$ & \multirow{2}{*}{$<0.001$} \\
\hline No & $68.33(328)$ & $73.63(201)$ & 61.35 (127) & & 78.83 (108) & 82.14 (115) & $51.72(105)$ & \\
\hline
\end{tabular}

Overall, $22 \%$ of survey respondents felt even if they wanted to, they would not be able to return to school when the pandemic was over. Only $9 \%$ of respondents in Delhi felt even if they wanted to, they would not be able to return to school when the pandemic was over $(p<0.001)$. Compared to girls, boys were more likely to report that they now spend more time on household chores than they did before the pandemic ( $41 \%$ vs. $28 \%, p<0.01)$. Individuals in Nepal reported a higher percentage of spending more time on household chores now than before the pandemic $(53 \%, p<0.001)$. Similarly, males were more likely than females to report they spend more time taking care of children and the elderly now than before COVID-19 (39\% vs. $26 \%, p<0.01$ ). Individuals in Nepal reported a higher percentage of spending more time taking care of children and the elderly now than before COVID-19 (48\%, $p<0.001)$.

Finally, when asked about the main challenge respondents are facing to continue learning while schools are closed, the most frequently occurring responses included not knowing what to do $(17 \%)$, or not having a reliable internet connection (16\%) (Figure 1). There were no differences by gender. However, there were differences by geographic location with slightly more respondents in Uttar Pradesh (23\%), when compared with Delhi $(18 \%)$ and Nepal $(13 \%)$, reporting that they do not know what to do $(p=0.055$, Figure 2$)$. 


\section{What is the MAIN challenge you are facing to continue learning while schools are closed?}

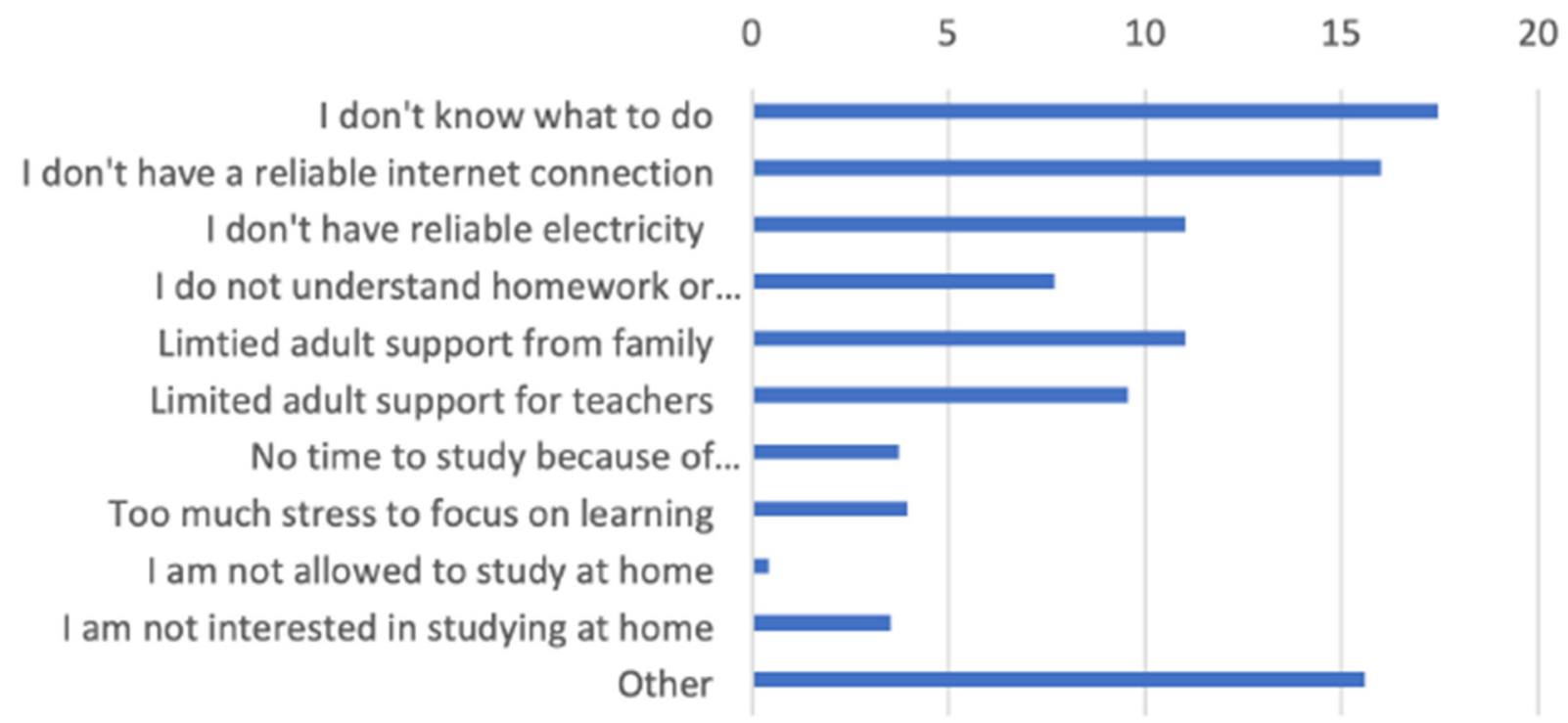

Figure 1. Challenges faced while schools are closed due to the pandemic, overall \%.

\section{What is the MAIN challenge you are facing to continue learning while schools are closed by Geographic location}

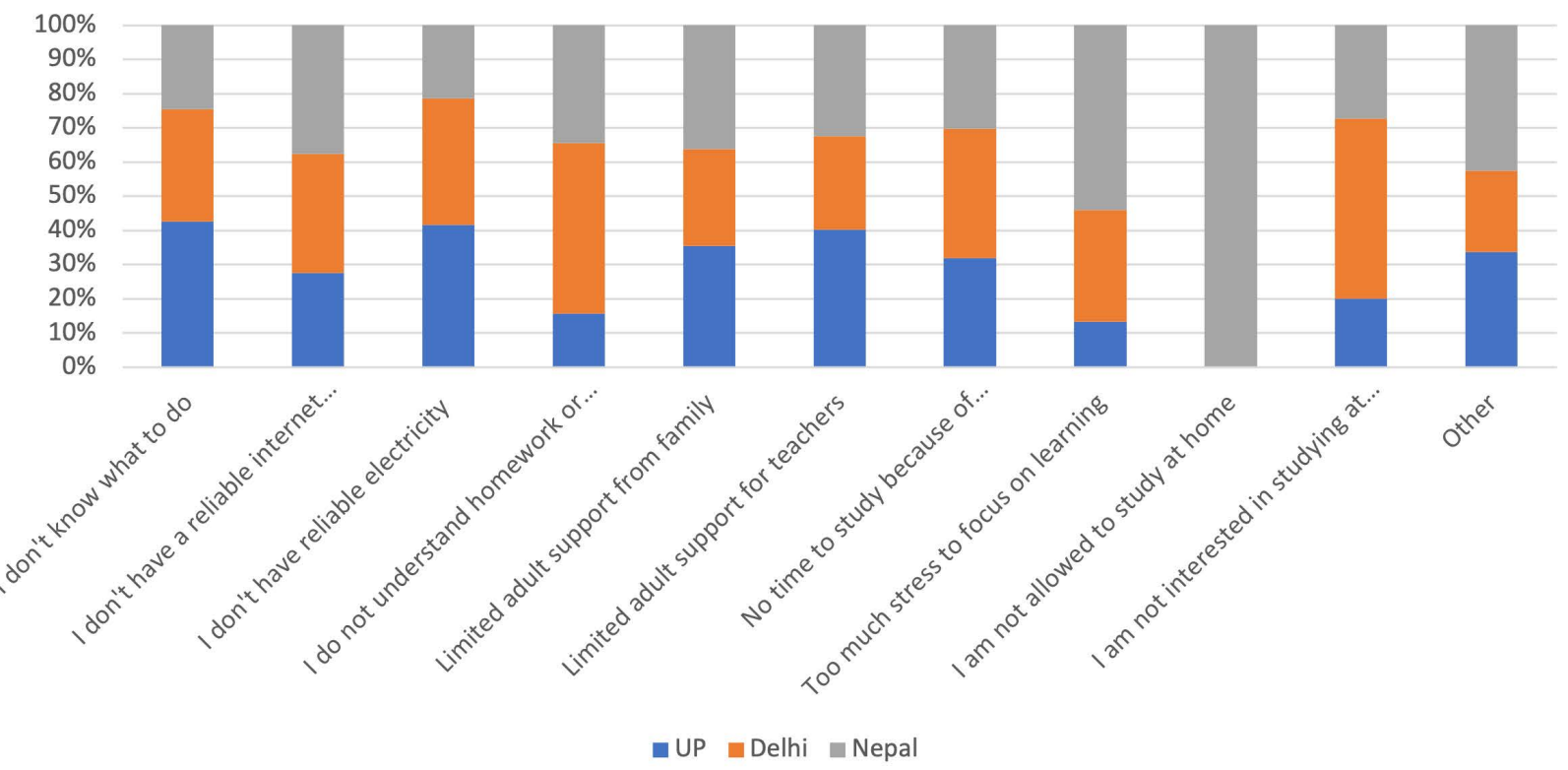

Figure 2. Challenges faced while schools are closed due to the pandemic by geographic location.

\section{Discussion}

The present study found that girls were more likely than boys to report wanting to return to school after the pandemic was over. It is well established that education and staying in school protects adolescent girls from early marriage and childbearing, leaving girls more vulnerable than boys during this pandemic [20-22]. Therefore, it is quite plausible that girls value their education and do not take their education for granted because they often have to fight to stay in school through their secondary high school 
years. This finding also suggests that adolescent girls are cognizant that they may have "more to lose" if they do not go back to school given increased risks for early marriage and childbearing. That said, this study was not able to explore how perceptions of early marriage and childbearing would influence these results. Further, it is also plausible that because girls have significantly more chores and household responsibilities when at home, they prefer being in school. Future research should explore this in more-depth. Adolescent boys, on the other hand, are less likely to perceive risks associated with dropping out of school given gender roles in South Asia, and therefore are less likely than girls to report wanting to return to school.

Not surprising, compared to girls, boys were more likely to report that they now spend more time on household chores than they did before the pandemic. According to the global UNICEF data from pre-pandemic times, girls between the ages of 5-14 spent 550 million hours on household chores which was 160 million more hours than boys in the same age groups [23]. In many ways, adolescent girls have often lived under a state of "lockdown" with limited mobility and other restrictions. During the pandemic's school closures, adolescent boys experienced a glimpse into the lives of their female counterparts, taking on increased household chores.

Education inequalities have long been a challenge in low-to-middle-income countries with considerable socioeconomic and gender disparities. As national and local lockdowns took hold during the COVID-19 pandemic in India and Nepal and schools closed, the widespread use of technology for remote and virtual learning exacerbated these inequalities. The present analysis found that adolescents in Uttar Pradesh reported a higher percentage of doing nothing while schools have been shut down compared to Delhi and Nepal. Uttar Pradesh respondents also reported a higher percentage of studying with their own books and a lower percentage of online/mobile learning, compared to Delhi and Nepal. Of the three locations, the Uttar Pradesh sample was more rural, and it is likely that these adolescents did not have access to technology and were therefore more likely to utilize lowtech methods for learning or spent more time disengaged from any type of learning. This is especially relevant for adolescent girls as they are less likely to have access to technology and mobile phones to engage in online learning. As South Asian countries move past lockdowns and schools re-open, it will be imperative for school leaders and teachers to mitigate learning losses while also addressing social and emotional well-being, with particular attention to gender disparities and how the pandemic differentially impacted boys and girls.

There are limitations to this study. These data are from a cross-sectional sample and therefore cannot imply causal inferences. The data were self-reported and on sensitive and new topics, including COVID-19. Given the data collection challenges during the COVID-19 pandemic, adolescent participants completed the surveys via "paper/pencil" and were not in a structured school environment but gathered in their communities and neighborhoods with local community-based organizations and research staff. Traditional paper surveys do not easily allow for low literacy and audio capabilities, and therefore it is possible that there were comprehension challenges. Further, paper surveys do not readily allow for privacy which may have also led to biased responses. Finally, it is important to note that $70 \%$ of respondents in Delhi did not think any households had been affected by COVID-19, followed by 52\% in Uttar Pradesh and 33\% in Nepal. Given this study was conducted immediately prior to the second surge of COVID-19 in South Asia, these findings may be conservative, and it is possible that participants' experiences have worsened. Despite these limitations, these findings provide insights into the experiences of adolescents during COVID-19, and subsequent school closures. These findings cannot be understated given the significant gains that have been made for adolescents, especially girls, in South Asia. 


\section{Conclusions}

Schools serve a critical role in the development of children and adolescents with a long-lasting impact into adulthood. Schools are not merely a place for academic learning, but school time and place foster life skills, provide an opportunity for positive growth, and protects girls from early marriage and childbearing. The findings in this study highlight how technology access and gender disparities and norms have influenced adolescent experiences during COVID-19 in South Asia. It is imperative as this pandemic continues and schools remain closed that we address the widening disparities to accessing a remote education, especially for adolescent girls.

Author Contributions: Conceptualization, N.N., M.L., R.H., J.L. and A.V.; methodology, N.N., M.L., R.H., J.L. and A.V.; formal analysis, N.N., M.L. and A.V.; writing-original draft preparation, N.N., M.L. and A.V.; writing-review and editing, N.N., M.L., R.H., J.L. and A.V.; project administration, N.N., M.L., R.H., J.L. and A.V. All authors have read and agreed to the published version of the manuscript.

Funding: Funding support was provided by Gender and Adolescence: Global Evidence (GAGE). GAGE was not involved in the conducting of the research or preparation of this article.

Institutional Review Board Statement: The study was conducted according to the guidelines of the Declaration of Helsinki and approved by the Institutional Review Board (or Ethics Committee) of The George Washington University (IRB \#191568).

Informed Consent Statement: Informed consent was obtained from all subjects involved in the study.

Data Availability Statement: The data are not publicly available as they were recently collected. They will be made available to the public later this year.

Acknowledgments: We would like to thank our local partners, Navsrishti in Delhi, Gramin Puranirman Sansthan in Lucknow, and The Story Kitchen in Nepal, for assistance with all the data collection efforts in each of these communities. It took numerous hours, emails, and Zoom calls to finalize the research instruments, measures, and data collection schedule. Thank you for allowing us to be a part of your communities. Your commitment to young people and gender equality is an inspiration. We would also like to thank Nidhi Dubey, Senior Vice President at Global Health Strategies for her leadership and dedication to this project.

Conflicts of Interest: The authors declare no conflict of interest. The funders had no role in the design of the study; in the collection, analyses, or interpretation of data; in the writing of the manuscript, or in the decision to publish the results.

\section{References}

1. The World Bank. Urgent. Effective Action Required to Quell the Impact of COVID-19 on Education Worldwide, January 2021. Available online: https://www.worldbank.org/en/news/immersive-story/2021/01/22/urgent-effective-action-required-toquell-the-impact-of-covid-19-on-education-worldwide (accessed on 23 June 2021).

2. Conto, A.; Carolina, M.; Akseer, S.; Dreesen, T.; Kamei, A.; Mizunoya, S.; Rigole, A. COVID-19: Effects of School Closures on Foundational Skills and Promising Practices for Monitoring and Mitigating Learning Loss; Innocenti Working Paper 2020-13; UNICEF Office of Research-Innocenti: Florence, Italy, 2020.

3. Borkowski, A.; Hares, S.; Minardi, A.L. With Schools Closed, Hundreds of Millions of Children Are Not Receiving School Meals, Center for Global Development, March 2020, Washington, DC. Available online: https:/ /www.cgdev.org/blog/schools-closedhundreds-millions-children-are-not-receiving-school-meals (accessed on 21 June 2021).

4. Memon, R.I.; Imran, N.; Aamer, I.; Sharif, M.I.; Bodla, Z.H.; Naveed, S. The Effect of Quarantine On The Emotional Well-being of Kids: A Systematic Review. J. Am. Acad. Child Adolesc. Psychiatry 2020, 59, S144. [CrossRef]

5. Jewkes, R.; Morrell, R. Hegemonic masculinity, violence, and gender equality: Using latent class Analysis to investigate the origins and correlates of differences between men. Men Masc. 2018, 21, 547-571. [CrossRef]

6. Yu, C.; Zuo, X.; Blum, R.W.; Tolman, D.L.; Kågesten, A.; Mmari, K.; De Meyer, S.; Michielsen, K.; Basu, S.; Acharya, R.; et al. Marching to a different drummer: A cross-cultural comparison of young adolescents who challenge gender norms. J. Adolesc. Health 2017, 61, S48-S54. [CrossRef] [PubMed]

7. CARE. Girl Driven Change-Meeting the Needs of Adolescent Girls During COVID-19 and Beyond. 2020. Available online: https: //www.care.org/wp-content/uploads/2020/10/CARE-USA-Adolescent-Girls-and-COVID-19-FINAL-Report.pdf (accessed on 30 June 2021). 
8. United Nations Children's Fund. The State of the World's Children 2011. Adolescence: An Age of Opportunity; UNICEF: New York, NY, USA, 2011. Available online: https: / / www.unicef.org/media/84876/file/SOWC-2011.pdf (accessed on 30 June 2021).

9. World Health Organization. Adolescent Health Research Priorities: Report of a Technical Consultation, 13th and 14th October 2015, Geneva, Switzerland. Available online: https:/ /apps.who.int/iris/handle/10665/203564 (accessed on 30 June 2021).

10. Fort, L.; Tembon, M. (Eds.) Girls' Education in the 21st Century: Gender Equality, Empowerment, and Economic Growth; The International Bank for Reconstruction and Development/The World Bank: Washington, DC, USA, 2008.

11. SCO and UNHCR (United Nations Education, Scientific, and Cultural Organization and United Nations High Commissioner for Refugees). Educational Responses to HIV and AIDS for Refugees and Internally Displaced Persons; Discussion Paper for DecisionMakers; UNESCO: Paris, France; UNHCR: Geneva, Switzerland, 2007.

12. Sahoo, S. Girls' Education in India: Status and Challenges. Int. J. Res. Econ. Soc. Sci. 2016, 6, 130-141.

13. Pinchoff, J.; Santhya, K.G.; White, C.; Rampai, S.; Acharya, R.; Ngo, T.D. Gender specific differences in COVID-19 knowledge, behavior and health effects among adolescents and young adults in Uttar Pradesh and Bihar, India. PLoS ONE 2020, 15, e0244053. [CrossRef]

14. Mahapatra, A.; Sharma, P. Education in times of COVID-19 pandemic: Academic stress and its psychosocial impact on children and adolescents in India. Int. J. Soc. Psychiatry 2020, 67, 397-399. [CrossRef] [PubMed]

15. Acharya, M.; Bennett, L. The Status of Women in Nepal: A Critical Review; Center for Economic Development \& Administration: Kathmandu, Nepal, 1981.

16. Pennels, L. Girls and Women's Education Policies and Implementation Mechanism, Case Study: Nepal; UNESCO Principal Regional Office for Asia and the Pacific: Bangkok, Thailand, 1998.

17. UNICEF Nepal. School Reopening Framework 2020. The Government of Nepal's Framework for Reopening Schools in the Context of COVID-19; UNICEF Nepal: Patan, Nepal, 2020.

18. Panthe, K.P.; McCutcheon, A.L. Gender Differences in Rural Urban Education in Nepal. Eur. J. Educ. Sci. 2015, 2, 61-79. [CrossRef]

19. Baird, S.; Małachowska, A.; Jones, N. COVID-19 Phone Survey (Round 1); Core Respondent Module; Gender and Adolescence: Global Evidence: London, UK, 2020.

20. Vyas, A.N.; Nagaraj, N.C.; Teklay, W.; Hingorani, R.; Luintel, J.; Landry, M. Measuring agency, voice, and gender attitudes among adolescents in South Asia. PLOS ONE 2021. under review.

21. Igras, S.M.; Macierira, M.; Murphy, E.; Lundgren, R. Investing in very young adolescents' sexual and reproductive health. Glob. Public Health 2014, 9, 555-569. [CrossRef] [PubMed]

22. Mmari, K.; Blum, R.W.; Atnafou, R.; Hilet, E.; de Meyer, S.; El-Gibaly, O.; Basu, S.; Bello, B.; Maina, B.; Zuo, X. Exploration of Gender Norms and Socialization Among Early Adolescents: The Use of Qualitative Methods for the Global Early Adolescent Study. J. Adolesc. Health 2017, 61 (Suppl. S4), S12-S18. [CrossRef] [PubMed]

23. United Nations Children's Fund. Harnessing the Power of Data for Girls: Taking Stock and Looking Ahead to 2030; UNICEF: New York, NY, USA, 2016. 